Journal of Applied Pharmaceutical Science Vol. 5 (11), pp. 117-120, November, 2015

Available online at http://www.japsonline.com

DOI: $10.7324 / \mathrm{JAPS} .2015 .501120$

ISSN 2231-3354 (cc) BY-NC-sA

\title{
Anti-inflammatory and analgesic activities of methanol extracts of stem bark of Anthocleista djalonensis in wistar rats
}

\author{
Olusayo Aderonke Shorinwa ${ }^{1 *}$, Adaora Obiageli Enemuoh ${ }^{1}$, Fidelia Ijeoma Uche ${ }^{2}$ \\ ${ }^{1}$ Department of Experimental Pharmacology and Toxicology, Faculty of Pharmaceutical Sciences, University of Port Harcourt, Nigeria. \\ ${ }^{2}$ Department of Pharmacognosy and Phytotherapy, Faculty of Pharmaceutical Sciences, University of Port Harcourt, Port Harcourt, Nigeria.
}

\author{
ARTICLE INFO \\ Article history: \\ Received on: 10/08/2015 \\ Revised on: 14/09/2015 \\ Accepted on: 01/10/2015 \\ Available online: $27 / 11 / 2015$ \\ Key words: \\ Anthocleista djalonensis, \\ anti-inflammatory, analgesic, \\ analgesymeter,
}

plethysmometer

\begin{abstract}
This study was carried out to evaluate the anti-inflammatory and analgesic activities of the stem bark extract in albino rats. Evaluation of the anti-inflammatory activity was done using fresh egg albumin induced rat paw edema with a plethysmometer, while the analgesic effect was determined using the analgesymeter mechanically induced pain. The methanolic extract of the stem bark of Anthocleista djalonensis was evaluated at $100 \mathrm{mg} / \mathrm{kg}$, $200 \mathrm{mg} / \mathrm{kg}$, and $400 \mathrm{mg} / \mathrm{kg}$ through the oral route. Indomethacin $(10 \mathrm{mg} / \mathrm{kg})$ was used as standard reference antiinflammatory and analgesic drug. Preliminary phytochemical screening showed the presence of tannins, flavonoids, saponins and deoxysugars. The different doses of the extract significantly inhibited the egg albumin induced inflammation $(\mathrm{P}<0.05)$ in a non-dose dependent manner. The extract also significantly inhibited the pain $(\mathrm{P}<0.05)$ mechanically induced on the rat paw by the analgesymeter. The findings of this study showed that the plant possess significant anti-inflammatory and analgesic activities.
\end{abstract}

\section{INTRODUCTION}

Medicinal plants are widely used for medications in Africa for the treatment and management of a myriad of diseases and according to daSilva Frutuoso et al., 2007, they have continued to play key roles in health care management around the world. The chemical diversities derivable from the plants make them important resource for the isolation of bioactive organic compounds (Basso et al., 2005). Inflammation is a protective response to an injurious stimulus such as infections, antibodies and physical injuries. The inflammatory process is intended to eliminate the initial cause of cell injury or necrotic cells that result from injury. Although inflammation helps clear infections, toxins, and initiates repair, the inflammatory reaction can cause considerable harm. The components of the inflammatory reaction that destroys and eliminates microbes and dead tissues are capable of injuring normal tissues (Kumar et al., 2009). There are various components to an inflammatory reaction

\footnotetext{
* Corresponding Author

Olusayo Aderonke Shorinwa, Department of Experimental

Pharmacology and Toxicology, faculty of Pharmaceutical Sciences, University of Port Harcourt, Nigeria. Email: sayoshorinwa@yahoo.com
}

that can contribute to the associated symptoms and tissue injury. Oedema formation, leukocyte infiltration and granuloma formation represent such components of inflammation (Mitchell and Cotran, 2000). In most cases, the inflammatory response eventually subsides, but if such a self-limiting regulation does not occur, the inflammatory response will require pharmacological intervention (Craig et al., 2003). Anthocleista djalonensis A. Chev (Gentianaceae) is commonly known as cabbage tree and produces fruits in Nigeria in October and November (De Ruijter, 2007). In Nigeria, it is called sapo in Yoruba,kwarii in Hausa, okpokolo in Igbo and osuo in Bayelsa state in Southern Nigeria. It is of medical knowledge that currently used anti-inflammatory and analgesic drugs are associated with side effects, an example of which is the gastrointestinal problems caused by some non-steroidal antiinflammatory drugs. There is therefore a profound need for research with ethnomedicinal plants, with the aim of developing new and potent anti-inflammatory and analgesic drugs from plant source but with less side effects. Bassey et al., 2009 reported that the ethanolic extract of the leaf and stem bark of the plant possesses considerable antiplasmodial activity. The aqueous and methanolic extract of the leaves of this plant was found to possess significant anti-inflammatory activity by Okunrobo et al., 2009 and Chah et al., 2006 reported its antimicrobial activity. Traditionally, 
Anthocleista djalonensis is used generally for the treatment of dropsy, swellings, oedema, liver problems, antidotes to venomous stings and bites and pain killer (Burkill, 1985).

This study therefore evaluated the anti-inflammatory and activities of Anthocleista djalonensis stem bark in wistar rats since no such study has been documented to the best of our knowledge.

\section{MATERIALS AND METHODS}

\section{Plant Material}

The stem bark of Anthocleista djalonensis was collected from the University of Port-Harcourt, Choba, Rivers state, Nigeria. The plant was authenticated at the Faculty of Pharmacy, University of Uyo, Nigeria, where a specimen has been deposited with a voucher number UUH 02/11.

The harvested bark was dried under shed for a period of one week. The dried bark was then reduced to fine powder with a mechanical grinder and stored in an air tight container.

\section{Extraction of Plant Material}

The powdered plant $(500 \mathrm{~g})$ was macerated with 2 litres of methanol for 72 hours. The product was then suction filtered using a suction pump and Whatman filter paper. The filtrate was concentrated to dryness with a rotary evaporator at $60{ }^{\circ} \mathrm{C}$ to give a greenish crude extract. The crude extract was then further dried over a water bath set at $40{ }^{\circ} \mathrm{C}$. This gave a dried extract with $34 \% \mathrm{w} / \mathrm{w}$ yield. This was stored in airtight container at a temperature of $4{ }^{\circ} \mathrm{C}$ for further use.

\section{Drugs and chemical}

Analytical grade of methanol manufactured by SigmaAldrich, Germany was obtained. Indomethacin (Kadcid) was purchased from Clarion Medicals, Lagos, Nigeria.

\section{Animals}

Twenty-five Wistar rats $(180 \mathrm{~g}-200 \mathrm{~g})$ of both sexes were obtained from the animal house of the Department of Pharmacology, Faculty of Basic Medical Sciences, University of Port Harcourt, Nigeria. The animals were allowed 7 days for acclimatization and were maintained under standard environmental conditions and with free access to feed and water ad libitum. They were starved for 24 hours prior to experiment but were granted access to water. All the standard ethical requirements for experimental animals were complied with.

\section{Phytochemical screening}

The methanol extract were screened for bioactive constituents using standard procedures to identify different compounds by characteristic colour changes as described by Harborne, 1998.

\section{Evaluation of analgesic activity}

The analgesic property of the plant extract was measured against mechanical stimuli using an Ugo Basileanalgesymeter (model 7200, UgoBasile, Italy). Wistar rats were grouped into five groups of five animals per group. In the experiment, the negative control animals, the positive control animals and the extract treated animals were tested with the analgesymeter. These animals (group 1-3) were administered 100,200 and $400 \mathrm{mg} / \mathrm{kg}$ of Anthocleista djalonensis extract. Group 4 animals were given $0.1 \mathrm{ml}$ normal saline and group 5 were given $7 \mathrm{mg} / \mathrm{kg}$ indomethacin through the oral route by means of a cannula.

The rats were restrained in an upright position with the right hand paw placed between the plinth and the plunger of the analgesymeter. A constant increasing force was then applied to the right hind paw. The weight that caused paw withdrawal (endurance threshold) in the different experimental groups was determined according to the method of Ndebia et al., 2007. Pain inhibition was calculated as;

$$
\text { Percentage pain inhibition }(\%)=\frac{\mathrm{F}_{\mathrm{t}-}-\mathrm{F}_{0} \mathrm{X}}{\mathrm{F}_{\mathrm{o}}}
$$

Where $\mathrm{F}_{\mathrm{o}}=$ Force at which the animal struggles to free its paw in a normal saline treated rat

$\mathrm{F}_{\mathrm{t}}=$ Force at which the animal struggles to free its paw, in animals treated with the extract or indomethacin. The pressure induced pain is measured in gram force $(\mathrm{gf})$.

\section{Evaluation of anti-inflammatory activity}

The method of Ndebia et al., 2007 was adopted with little modification. The animals were placed in 5 groups of 5 animals each, in different cages and labelled appropriately. Different doses of the extract $(100-400 \mathrm{mg} / \mathrm{kg})$ were administered to the animals. Group 1 was given $10 \mathrm{mg} / \mathrm{kg}$ indomethacin, group 2 was given $0.1 \mathrm{ml}$ normal saline and group $3-5$ were given $100-400 \mathrm{mg} / \mathrm{kg}$ of extract.

After 30 minutes of administering the plant extracts and control drugs, acute inflammation was induced, by intraplantar administration of $0.1 \mathrm{ml}$ of fresh egg albumin in the left hind paw of the animals. The paw volume was measured before injecting the phlogistic agent (egg albumin).The paw volume was also measured 1, 2, 3 and 4 hours after inducing inflammation, using a plethysmometer (UgoBasile $\mathrm{N}^{0} 7140$ ). Inflammation was expressed as an increase in paw volume due to egg albumin injection as described by Ndebia et al., 2007.

Inflammation was calculated as;

$$
\Delta \mathrm{V}=\mathrm{V}_{\mathrm{t}}-\mathrm{V}_{\mathrm{o}}
$$

Where $\Delta \mathrm{V}=$ Change in paw volume (degree of inflammation) $\mathrm{V}_{\mathrm{t}}=$ Left hind paw volume at time, $\mathrm{t}$

$\mathrm{V}_{\mathrm{o}}=$ Left hind paw volume before sub-plantar administration of the phlogistic agent (egg albumin)

Percentage inhibition (I \%) was calculated as;

$$
\begin{aligned}
& =\left(\underline{\mathrm{V}}_{\mathrm{t}}-\mathrm{V}_{0}\right) \mathrm{C}-\left(\mathrm{V}_{\underline{t}} \underline{\mathrm{V}}_{\mathrm{o}}\right) \underline{\mathrm{E}} \times 100 \\
& \left(\mathrm{~V}_{\mathrm{t}}-\mathrm{V}_{\mathrm{o}}\right) \mathrm{C}
\end{aligned}
$$

Where $\mathrm{E}=$ Experimental group treated with extracts or indomethacin.

$\mathrm{C}=$ Control group treated with normal saline. 


\section{Statistical analysis}

The results were expressed as mean \pm SEM. Statistical analysis of data was done using one-way analysis of variance (ANOVA) followed by student's t-test. The statistical analysis was done to determine the significance of difference between the control groups and the treated groups. P-values $<0.05$ were considered to be statistically significant.

\section{RESULTS AND DISCUSSION}

Phytochemical screening revealed the presence of deoxysugars, flavonoids, tannins and saponins in the stem bark of Anthocleista djalonensis (Table 1). The plant extract at $100 \mathrm{mg} / \mathrm{kg}$, $200 \mathrm{mg} / \mathrm{kg}$, and $400 \mathrm{mg} / \mathrm{kg}$ significantly inhibited acute inflammation caused by egg albumin injected into the rat paw. The degree of inflammation inhibition expressed in percentages is depicted in Table 2 above. The highest inflammatory inhibitions was observed after four hours of treatment with the extracts, with the $100 \mathrm{mg} / \mathrm{kg}, 200 \mathrm{mg} / \mathrm{kg}$, and $400 \mathrm{mg} / \mathrm{kg}$ doses of the extract inhibiting inflammation at $72 \%, 55 \%$ and $90 \%$ respectively. The reference control drug, indomethacin, also showed its highest inflammatory inhibition after four hours, with $60 \%$ inflammation inhibition. The degree of pain inhibition expressed in percentages is depicted in Table 4 above.
The extract at the doses of $100 \mathrm{mg} / \mathrm{kg}, 200 \mathrm{mg} / \mathrm{kg}$, and $400 \mathrm{mg} / \mathrm{kg}$, inhibited the mechanical pain caused by the increasing pressure on the rat paw by the plunger and the plinth of the analgesymeter. The highest inhibition of pain was observed after two hours of treatment with the extract and the reference drug indomethacin.

After two hours, the extract at $100 \mathrm{mg} / \mathrm{kg}, 200 \mathrm{mg} / \mathrm{kg}$, and $400 \mathrm{mg} / \mathrm{kg}$ body weight showed $261 \%, 477 \%$ and $395 \%$ inhibition of pain respectively, while the reference drug indomethacin inhibited pain by $270 \%$. Various doses of the extract inhibited pain stimulus when compared to the negative and positive control. The observed significant anti-inflammatory and analgesic activities of this plant could be attributed to the presence of phytoconstituents such as flavonoids and tannins. Flavonoids have been reported to have antioxidant and anti-inflammatory properties due to their inhibitory effects on enzymes involved in the production of the chemical mediators of inflammation by Uche et al., 2009 while these constituents have been shown to exert antiinflammatory and analgesic activities as observed by Agada et al., 2005. The plant extract significantly inhibited pain caused mechanically by increasing pressure exerted on rat paw by the plunger and plinth of the analgesymeter. According to Ndebia et al., (2007), the analgesymeter provides a model for the study of non-inflammatory pain.

Table 1: Phytochemical screening.

\begin{tabular}{lc}
\hline CHEMICAL CONSTITUENT & OBSERVATION \\
\hline Alkaloids & - \\
Deoxysugars & + \\
Carbohydrates & - \\
Flavonoids & + \\
Tannins & +++ \\
Saponins & + \\
Phlobatannins & - \\
\hline
\end{tabular}

$+\quad=$ Present, $+++\quad=$ Highly present, - = Absent

Table 2: Mean volume of paw oedema (mL).

\begin{tabular}{|c|c|c|c|c|c|}
\hline \multirow[t]{3}{*}{ Group } & \multirow{3}{*}{$\begin{array}{c}\text { Dose } \\
\mathrm{mg} / \mathrm{kg}\end{array}$} & \multicolumn{4}{|c|}{ Mean volume of paw oedema $(\mathrm{ml})(\%$ inhibition) } \\
\hline & & & & Time (Hours) & \\
\hline & & 1 & 2 & 3 & 4 \\
\hline Control & $5 \mathrm{ml}$ & $1.27 \pm 0.36$ & $1.16 \pm 0.41$ & $1.11 \pm 0.41$ & $1.08 \pm 0.36$ \\
\hline Indomethacin & 10 & $1.04 \pm 0.36(18)$ & $0.8 \pm 0.36(31)$ & $0.89 \pm 0.36(20)$ & $0.43 \pm 0(60)^{* *}$ \\
\hline A. djalonensis & 100 & $0.79 \pm 0.36(38)$ & $0.67 \pm 0.27(42)^{*}$ & $0.94 \pm 0.36(15)$ & $0.30 \pm 0(72)^{* *}$ \\
\hline A. djalonensis & 200 & $1.14 \pm 0.41(10)$ & $0.84 \pm 0.36(28)$ & $0.48 \pm 0(57) * *$ & $0.46 \pm 0(57)^{*}$ \\
\hline A. djalonensis & 400 & $0.74 \pm 0.27(43)$ & $0.32 \pm 0(72)^{* *}$ & $0.24 \pm 0(73) * *$ & $0.11 \pm 0(90) * * *$ \\
\hline
\end{tabular}

$* \mathrm{P}<0.05, * * \mathrm{P}<0.01, * * * \mathrm{P}<0.001,(\mathrm{n}=5)$.

Table 3: (Mean values in gram force \pm Standard Error of Mean).

\begin{tabular}{|c|c|c|c|c|c|}
\hline \multirow[t]{2}{*}{ Group } & \multirow{2}{*}{$\begin{array}{c}\text { Dose } \\
\mathrm{mg} / \mathrm{kg}\end{array}$} & \multicolumn{4}{|c|}{ Time (Hours) } \\
\hline & & 0 & 1 & 2 & 3 \\
\hline Control & $5 \mathrm{ml}$ & $120 \pm 6.99$ & $129 \pm 12.75(0)$ & $119 \pm 11.05(3)$ & $128 \pm 13.40(8)$ \\
\hline Indomethacin & 10 & $129 \pm 12.75$ & $240 \pm 25.34(86) * *$ & $477 \pm 25.35(270) * * *$ & $299 \pm 35.18(132)^{* *}$ \\
\hline A. djalonensis & 100 & $128 \pm 13.40$ & $228 \pm 24.71(78)^{* *}$ & $463 \pm 13.84(261) * * *$ & $463 \pm 37.42(262)^{* * * *}$ \\
\hline A. djalonensis & 200 & $119 \pm 11.05$ & $198 \pm 17.29(66)^{* *}$ & $687 \pm 13.44(477) * * *$ & $434 \pm 55.65(265)^{* *}$ \\
\hline A. djalonensis & 400 & $126 \pm 9.50$ & $312 \pm 51.41(146)^{*}$ & $624 \pm 33.27(395) * * *$ & $570 \pm 33.27(352)^{* * *}$ \\
\hline
\end{tabular}

$* \mathrm{P}<0.05, * * \mathrm{P}<0.01, * * * \mathrm{P}<0.001,(\mathrm{n}=5)$ 
The extract significantly inhibited the analgesymeter pressure induced pain on the rat paw. Indomethacin is a nonsteroidal anti-inflammatory drug (NSAID) with anti-inflammatory, analgesic and antipyretic activity. These pharmacological effects are mediated through inhibition of the enzyme cyclooxygenase (COX-2), the enzyme responsible for catalyzing the rate-limiting step in prostaglandin synthesis via the arachidonic acid pathway. This analgesic effect of NSAIDS has been reported to result from peripheral mechanisms in animal studies (Lim et al., 1964; Ferreira et al., 1978). Indomethacin has been reported to have a component in its analgesic action which affects the central nervous system. A previous study of patients with a sectioned spinal cord suggests that NSAIDs exert this analgesic effect on the central nervous system principally at the supraspinal level (Willer et. al, 1990. Hence, this extract may also possess some degree of central analgesic activity. Egg albumin-induced paw edema in rats is an in vivo model of inflammation used to screen agents for antiinflammatory effect (Amos et al., 2002) and has also been shown to be sensitive to cyclooxygenase inhibitors which act primarily through the inhibition of prostaglandin synthesis (Seibert et al., 1994). Chemical mediators such as histamine, serotonin (5-HT), kinins and prostanoids have been known to mediate an acute inflammation induced by phlogistic agents such as fresh egg albumin (Marsha-Lyn et al., 2002). The extract produced a significant inhibitory effect on rat paw edema. From these observations, it may be suggested that the plant extract acts both centrally in inhibiting pain as well as peripherally, as projected by its anti-inflammatory and analgesic activity. The phytochemical constituents of Anthocleista djalonensis including the tannins and flavonoid, thus contributes to the observed anti-inflammatory and analgesic activity of the plant. This corroborates the report of Pradeep Kumar et al., 2015 which stated that the presence of alkaloids, steroids, flavonoids in ethyl acetate extract of Peganumharmala (Linn) seeds could be attributed for its analgesic and anti-inflammatory activities.

\section{CONCLUSION}

The findings of the study has shown that the stem bark extract of Anthocleista djalonensis contains bioactive phytochemical constituents. It may thus be concluded that the stem bark extract of Anthocleista djalonensis possesses anti inflammatory and analgesic properties which can be due to its phytochemical constituents.

\section{CONFLICT OF INTEREST.}

The authors hereby declare that we have no conflict of interest.

\section{REFERENCES}

Agada LO, Asije O, Okeri H. Anti-diarrhoeic effects of leaf extract of Ipomoea involucrate. Nig J Pharm Res, 2005, 4(1); 11-4

Amos S, Chindo B, Edmond I, Akah P, Wambebe C, Gamaniel K. Anti-inflammatory and anti-nociceptive effects of Ficusplaty phylla in rats and mice. J Herbs Spices Med Plants, 2002, 9; 47 - 53
Bassey AS, Okokon JE, Etim EI, Umoh FU, Bassey E. Evaluation of the in vivo antimalarial activity of ethanolic leaf and stem bark extract of Anthocleista djalonensis . Indian J Pharmacol, 2009, 41 (6); 258-261.

Basso LA, Da Silva LH, Fett-Neto AG, De Azevedo Jr WF, Moreira Ide S, Palma MS, Calixto JB, Astolfi FS, Dos Santos RR, Soares MB, Santos DS . The use biodiversity as a source of new chemical entities against defined molecular targets for treatment of malaria, tuberculosis and T-cell mediated diseases: A review. MemInst Oswaldo Cruz, 2005, 100 (6); 475-506.

Burkill HM. 1985. The useful plants of West Tropical Africa. 2nd Edition. Volume 1, Families A-D. Royal Botanic Gardens, Kew, United Kingdom. pp. 960.

Chah KF, Eze CA, Emuelosi CE, Esimone CO. Antibacterial and wound healing properties of methanolic extracts of some Nigerian medicinal plants. J Ethnopharmacol. 2006, 104; 164-167.

Craig RC, Stitzel RE. 2003 Modern Pharmacology with Clinical Applications. Lippincott William and. Wilkins, Sixth edition. pp 364-. 373.

De Ruijter A. Anthocleista djalonensis A Chev .Record from Protabase. $\mathrm{http}: / / \mathrm{www}$.prota4u.org/protav8.aspg=pe\&p=Anthocleistdjalonensis 2007

Ferreira SH, Lorenzetti BB, Correa FMA. Central and peripheral anti-analgesic action of aspirin-like drugs. Eur J Pharnacol, 1978, 53; 30-48.

Frutuoso VS, Monteiro MM, Amendoeira FC, Almeida ALF, Nascimento DD, Berenger ALR, Kaplan MAC, Figueiredo MR, Bozza PT, Neto HCCF. Analgesic and anti-inflammatory activity of the aqueous extract of Rheedia longifolia. Planch and Triana. Mem Inst Oswaldo Cruz, 2007, 102 (1); 91-96

Harborne JB. 1998. Phytochemical Methods: A Guide to Modern Techniques of Plant Analysis. 3rd ed., London; Chapman and Hall

Kumar K, Abbas AK, Fausto N, Mitchell RN. 2007. Robins Basic Pathology $8^{\text {th }}$ Edition. Saunders, pp 960

Kumar MRP, Joshi SD, Kulkarni VH, Savant C. Phytochemical screening and evaluation of analgesic, anti-inflammatory activities of Peganum harmala Linn., seeds in rodents. J App Pharm Sci, 2015, 5 (5); 052-055

Lim RK, Guzman F, Rodgers DW, Goto K, Braun C, Dickerson GD, Engle RJ. Site of action of narcotic and non-narcotic analgesics determined by blocking bradykinin-evoked visceral pain. Arch Int Pharmacodyn Ther.1964, 152; 25-58

Lorke D. A new approach to practical acute toxicity testing. Arch Toxicol, 1983,54 (4); 275-287.

Marsha-Lyn M, Mckoy G, Everton T, Oswald S. Preliminary investigation of the anti-inflammatory properties of an aqueous extract from Morinda citrifoli (Noni). Proc West Pharmacol Soc, 2002, 45; 76-78.

Mitchell RN, Cotran RS. 2000. In: Robinsons Basic Pathology, pp. 33-42, Harcourt Pvt., New Delhi, India, 7th edition.

Ndebia EJ, Kamgang R, Chungag Anye BN. Analgesic and Antiinflammatory properties of aqueous extract from leaves of Solanum torvum (Solanaceae). Afr J Trad, 2007, 4(2): 240-244.

Nkeh CAB, Njamen D, Wandji J, Fomum Z, Dongmo A, Nguelefack TB, Wansi B, KamanyiA. Anti-inflammatory and analgesic effect of Drypermolundein A, a sesquiterpene lactone from Drypetes molunduana. Pharm Biol, 2002, 4; 26-30.

Okunrobo L, Usifoh, C, Ching P, Bariweni M. Anti-inflammatory evaluation of methanol extract and aqueous fraction of the leaves of Anthocleista djalonensis A. Chev (Gentianaceae). IntJ Pharmacol, 2009, 7(1); 27

Okwu DE, Josiah C. Evaluation of the chemical composition of two Nigerian medicinal plants.Afr J Biotechnol, 2006, 5(4); 357-61

Seibert K, Zhang Y, Leahy K, Hauser S, Masferrer J, Perkins W, Lee L, Isakson P. Pharmacological and biochemical demonstration of the role of cyclooxygenase 2 in inflammation and pain. Proc Nat Acad Sci, 1994, 91(25); 12013-12017.

Willer JC, De Brouker T, Bussel B, Roby-Bramy A, Harrewyn JM. Central analgesic effect of ketoprofen in humans: electrophysiological evidence for a supraspinal mechanism in a double blind crossover study. Pain, 1990; $38: 1-7$

\section{How to cite this article:}

Olusayo Aderonke Shorinwa, Adaora Obiageli Enemuoh, Fidelia Ijeoma Uche. Anti-inflammatory and analgesic activities of methanol extracts of stem bark of Anthocleista djalonensis in wistar rats. J App Pharm Sci, 2015; 5 (11): 117-120. 